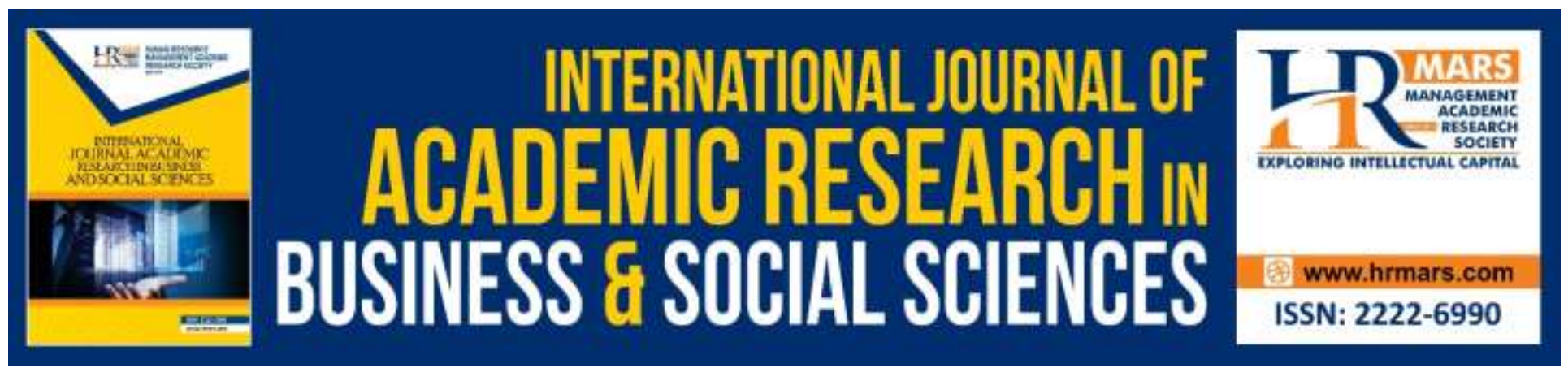

\title{
Literature Review on Concept of Tafakkur in Islamic Mysticism
}

Akila Mamat, M.Safri Ali, Syed Hadzrullathfi Syed Omar, Zaida Zainal Abidin, Aminudin Basir@ Ahmad, Shumsudin Yabi

To Link this Article: http://dx.doi.org/10.6007/IJARBSS/v9-i4/5816 DOI: $10.6007 /$ IJARBSS/v9-i4/5816

Received: 12 Feb 2019, Revised: 18 March 2019, Accepted: 30 March 2019

Published Online: 03 April 2019

In-Text Citation: (Mamat et al., 2019)

To Cite this Article: Mamat, A., Ali, M. S., Omar, S. H. S., Abidin, Z. Z., Ahmad, A. B. @, \& Yabi, S. (2019). Literature Review on Concept of Tafakkur in Islamic Mysticism. International Journal of Academic Research Business and Social Sciences, 9(4), 44-54.

Copyright: (c) 2019 The Author(s)

Published by Human Resource Management Academic Research Society (www.hrmars.com)

This article is published under the Creative Commons Attribution (CC BY 4.0) license. Anyone may reproduce, distribute, translate and create derivative works of this article (for both commercial and non-commercial purposes), subject to full attribution to the original publication and authors. The full terms of this license may be seen

at: http://creativecommons.org/licences/by/4.0/legalcode

Vol. 9, No. 4, 2019, Pg. 44 - 54

http://hrmars.com/index.php/pages/detail/IJARBSS

JOURNAL HOMEPAGE

Full Terms \& Conditions of access and use can be found at http://hrmars.com/index.php/pages/detail/publication-ethics 


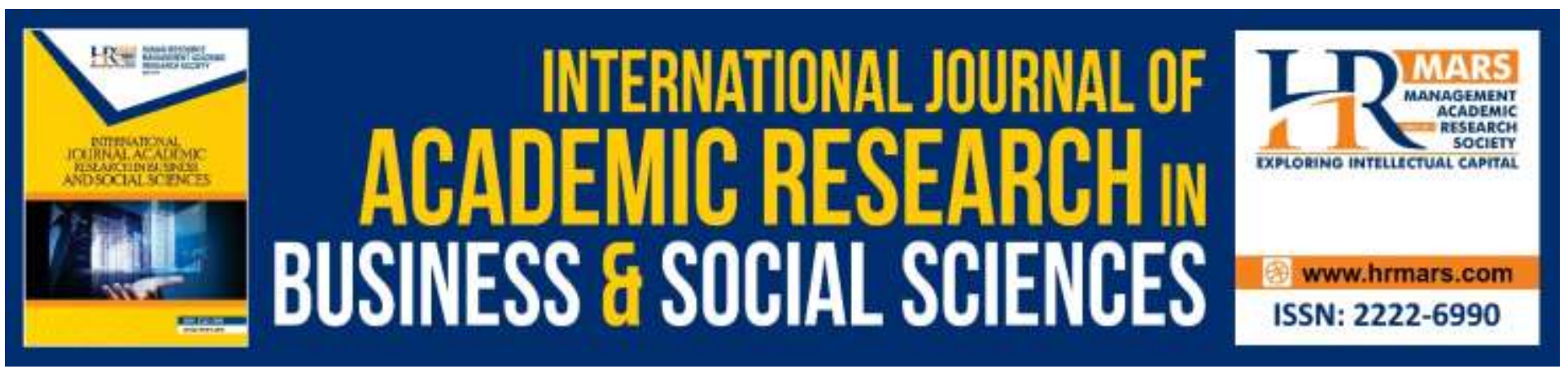

\title{
Literature Review on Concept of Tafakkur in Islamic Mysticism
}

\author{
Akila Mamat, M. Safri Ali, Syed Hadzrullathfi Syed Omar, Zaida \\ Zainal Abidin, Shumsudin Yabi \\ Universiti Sultan Zainal Abidin (UniSZA), Kampus Gong Badak,21300, Kuala Nerus, Terengganu, \\ Malaysia \\ Email: akila@unisza.edu.my
}

\begin{abstract}
Aminudin Basir@ @ Ahmad
Pusat Citra Universiti, Universiti Kebangsaan Malaysia,43600 UKM Bangi, Selangor Darul Ehsan Malaysia, Felo Bersekutu Institut Islam Hadhari, Universiti Kebangsaan Malaysia Email:manhaj@ukm.edu.my
\end{abstract}

\begin{abstract}
Tafakkur is an act of thinking, contemplating, reflecting, training and tadabbur that encompass human's mind, heart and spiritual. Thus, this study was conducted to further elaborate on tafakkur by realizing three selected objectives. Which is, explaining the consept of tafakkur, explaining the concept of tafakkur according to Islamic scholars and identifying the concept of tafakkur practiced by the Sufis. The methodology of this study is a library study to collect information, data and theories involved. Then, the data were analyzed by using content analysis method. The results of the study found that the practice of tafakkur produces individuals who are enlightened (Ulu al-Bab), have a strong hold to a knowledge, not easily influenced by others and able to see the wisdom behind a test. The practice of tafakkur also benefits the body and the soul of the practitioner plus to the community surrounding. In addition, the practice of tafakkur have become routine worship to Sufis members then accompanied by other tasawwuf elements. For example, element of 'uzlah, suluk, khulwah, dhikir, riyadah and muraqabah so that the tafakkur practice is more complete and effective. The ultimate goal of tafakkur practice is to know Allah SWT with the ultimate knowledge through the concept of al-Fana', al-Baqa and Ma'rifah Allah.
\end{abstract}

Keywords: Concept of Tafakkur, al-Fana', al-Bawa', Ma'rifah Allah 


\section{Introduction}

The practice of tafakkur have been practiced thousand years ago by people who are enlightened. Among them, Prophet Muhammad saw himself practice tafakkur as a method to contemplate the power of Allah SWT, expecting guidance and solutions to the problems faced. He always isolate himself and practice tafakkur in cave of Hira' consistenly without ever giving up and finally receive the relevation and guidance from Allah SWT when he was 40 years old. Therefore, Prophet Muhammad SAW is known as the savior of the creed and human civilization from continues to be covered in the darkness of jahiliyyah. Furthermore, the practice of tafakkur is recommended by Allah SWT. Allah said in az- Zariat verse 51: 21, which means:

Meaning: "And in your own selves! So, do you not perceive?".

In addition, Islam has also put reason in high places and the use of sensible minds coincides with the norms of the teachings of Islam itself. In this regard, the practice of thinking toward good and benefits is highly encouraged. The proof is that Allah SWT makes reason as a place of acceptance of Islamic law as it has in the study Maqasid al-Shariah ad Philosopyh of Islamic Law: A System Approach by Auda (2008: 145) and Allah SWT also protects the mind from corruption by prohibiting the use of intoxicants such as drugs, alcohol and the act of thinking beyond boundaries so that the mind is always healthy and sane.

\section{The Concept of Tafakkur in General}

With regard to the meaning of tafakkur, al-Ghazzali (2005: 188) in his books Mukasyafah al-Qulub, al-Muqarrab ila 'Allam al-Ghuyub has defined, tafakkur is a way of thinking deeply until the wisdom and the rational comes out awhich can produce knowledge confidently and free from blind taqlid. As for al-Munajiid (2009: 7) said in his essay titled al-Tafakkur, tafakkur means observation and management of the heart in accepting and understanding the meaning behind the incident.

So it is understandable that tafakkur is a prudent thought practice to see the wisdom behind an event, to increase faith, to achieve the reality of something and to calm down from any negative elements. al-Munajjid (2009: 7) adds tafakkur also able to alter the perceptions of a Muslim against the test that affects and assumes that all the hardships can erase all the sin, elevated by Allah SWT and rewarded from Him. Therefore, tafakkur can increase faith in Allah SWT and assume that each test has its own wisdom.

In addition, al-Suyuti (2009: 61) states that the practice of tafakkur also serves as a gesture so that the human beings always remember the blessings given by Allah SWT and also remind that only to Allah SWT only where humanity complains and asks for help. Next, so the people be aware of the rewards and promises of Allah SWT on every act of their deeds.

Al-Ghazzali (2005: 20) reminiscent, the practice of tafakkur is one of the ways to avoid receiving a knowledge and practice blindly. According to him, thinking, researching and deeply studying about the fields involved and the knowledge they learn will be able to satisfy, increase confidence and can be disseminated to others. Furthermore, issuing greater and useful benefits to 
INTERNATIONAL JOURNAL OF ACADEMIC RESEARCH IN BUSINESS AND SOCIAL SCIENCES

Vol. 9, No. 4, April, 2019, E-ISSN: 2222-6990 C 2019 HRMARS

all the institutions. Most importantly, the practice of tafakkur is the cause of the blessings of Allah SWT and is classified in the muhsinin. Allah said in Luqman verse 31: 1-3, which means:

Meaning; "Alif Lam Mim. These are verses of the Wise Book. A guidance and mercy for those who are good in their deeds".

Al-Qurtubi (2005:169) in his book book al-Jami fi Ahkam al-Qur'an added, the practice of tafakkur also serves as a training to the mind to think well and consider something fairly because Islam puts reason in high places and make reason as a place of legal acceptance. Hence, protecting the mind is one of the five Maqașid al-Syari ah.

Furthermore, al-Ghazzali (1968: 133) says tafakkur can be a solution if there is any confusion in a matter. As a matter of fact, he always practice tafakkur and chooses appropriate places to implement the practice. For example, in the year 1102 AD he was on leave from his duty as a teacher in the Nizamiyyah madrasah solely for practicing tafakkur in the mosque of Damascus (Griffel, 2009: 322).

Meanwhile, IbnQayyim (2015: 215) said that the practice of tafakkur is intended to remind ourselves not to forget the purpose of Allah SWT in creating mankind, to prepare supplies after death, to call upon mankind for good and peace as the purpose of tafakkur also to gain salvation and success in the world and the hereafter.

Accordingly, IbnTaymiyyah (1989: 13) states in his writings al-'Ubudiyyah, the Salik must prepare themselves with a sufficient knowledge in order to understand the path and challenge of tafakkur for them to achieve the true purpose of tafakkur and to be a devout servant, to be grateful and leave bad deeds. Al-Ghazzali (2005: 131) also agrees and affirms that tafakkur is one of the qualities of the believer because of the fact that they are able to attain knowledge that can assure their confidence in Allah SWT, to lead a practice in accordance with the Shari'ah and to avoid from doing things that is unpleasant to Allah SWT.

From the discussion, it is understood that the practice of tafakkur produces many benefits to its practitioners, especially from the point of worship. As explained by al-Sistani (2008: 80) in his book entitled Manhaj al-Salihin al-'Ibadat al-Mu 'amalat, that the main worship is to think about the creation of Allah SWT because it can magnify Him and realize that human is a weak servants that always need the help of Allah SWT.

While al-Suyuți (2009: 207) propose that rational and profound thinking is a symbol of the livelihood of the society that is enlightened, the characteristics of the pious people and the good association with others. If the practice becomes an obligation for every individual, it will diminish social problems in society. On the contrary, there will be feelings of compassion, good morals, sensible souls and minds. 
INTERNATIONAL JOURNAL OF ACADEMIC RESEARCH IN BUSINESS AND SOCIAL SCIENCES

Vol. 9, No. 4, April, 2019, E-ISSN: 2222-6990 @ 2019 HRMARS

In general, tafakkur is a practical way of remembering Allah SWT, perfecting worship to Allah, achieving the true essence of knowledge, solving problems plus to produce high-confidence human, knowledgeable and free from ignorance. Thus, the concept of tafakkur in tasawwuf can have a positive impact on the souls, emotions and physical aspects of the salik as well as to the communities around them.

\section{Concept of Tafakkur According to Islamic Scholar}

The concept of tafakkur has been widely discussed by authorized Islamic scholars. Especially the effectiveness of tafakkur practice in forming a superior Muslim personality, an intact soul with a strong faith. For example, al-Qusyairi (2003: 604) says tafakkur can help the salik to achieve and understand the concept of al-Fana ' and al-Baqa'. Al-Fana' is the desire of salik to destroy itself. That is, the loss of self-consciousness related to the condition and self-esteem.

Al-Țusi (2006: 19) also mention, al-Fana 'is the loss of the nature of the soul and the desire. So, whoever succeeds in subjugating the desire have succeed in mastering the concept of al-Fana ' and able to obey and know Allah SWT in true essence then succeed in achieving al-Baqa'. As He mentioned in surah al-Nahl, verse16: 96:

Meaning: "What is with you shall perish and what is with Allah shall last. And certainly, we shall bless those who observed patience, with their reward for the best of what they used to do".

According to al-Qusyayri (2003: 604), al-Baqa 'is the perpetuity of commendable attributes after the fall or destruction of despicable attributes. Al-Baqa ' is also a way to meet Allah SWT and reach Ma'rifah Allah. So to get the path, the salik should always works on their tafakkur, practicing and be thoughtful. Allah said in al-Rahman verse 55: 26-27, which means:

Meaning : "Everyone who is on it (earth) has to perish. And your Lord's Countenance will remain, full of majesty, full of honour".

After salik succeeded in mastering the concepts of al-Fana ' and al-Baqa', al-Ghazzali (1968: 29) explains in Minhaj al-Abidin Ila Jannati Rabba al- 'Alamin, it means that Salik has reached Ma'rifah Allah which is the main purpose of tafakkur in tasawwuf. Ma rifah Allah is a knowledge that can affirm the confidence towards Allah SWT without a slight doubt and confusion in it and also able to send someone to testimony God directly. In addition, able to understand God's laws more regularly covering all things.

Al-Kalabazi (1998: 158) also said, Ma'rifah Allah is a tasawwuf level which contains the knowledge of the divine nature which is a knowledge at the highest level that relates to the secrets of the heart and mind that can be achieved with tafakkur, dhikir, khulwah, 'uzlah, suluk or any terms that refer to the condition of the salik that isolate themselves to be able to reflect into him with the spiritual eye. Tafakkur at this level will bring salik into elements of muraqabah, mukasyafah and muhaḍarah musyahadah. 
Next, 'Abd al-Qadir' Isa (2007: 20) also agrees and thinks, tafakkur is one of the most important elements of tasawwuf and able to connect to Ma 'rifat Allah because tafakkur contains the word dhikir so that they will always remember Allah SWT. In addition, tafakkur practice will only be effective and perfect if accompanied by other tasawwuf methods. For example al-Ghazzali (2005: 48) says in the book Ihya "Ulum al-Din, practice of tafakkur should be accompanied by other tasawwuf methods, such as 'uzlah, khulwah, dhikir, riyadah and muraqabah in order to achieve the true essence and purpose of tasawwuf.

Then, Muhamad Taqiyudin (2009: 70) also argued, The perfect tafakkur should involve both the physical body and the spiritual. Among the ways and forms of tafakkur involving the spiritual is dhikir, khulwah, 'uzlah and muraqabah. The practice is aimed at strengthening the heart to always be devoted to worshiping Allah SWT. Al-Baghdadi (1990: 218) also agreed with the opinion and added, tafakkur in tasawwuf can only be achieved with riadah and earnest effort such as self restrain from sinful desire and leaving unnecessary thing and not just blindly following opinions of other people.

That opinion coincides with the view of al-Ghazzali (1968: 130) which declares that tasawwuf is a way to combat lustful desires in earnest, worship with sincerity, avoid the disgraceful nature and leave the vain thing in order to solely worshiping to Allah SWT wholeheartedly. Furthermore, tafakkur practice is also a noble practice inherited by the prophets.

The proof, al-Buți (2010: 73) says in Figh al-Sirah al-Nabawiyyah Ma`a Mujaz Li Tarikh Li alKhilafah al-Rasyidah, Prophet Muhammad SAW always practice tafakkur and 'uzlah to find the light of guidance to illuminate the day of jahiliyyah at that time. As a result, Allah SWT has provided guidance in the form of the Qur'an and the hadith. This matter was emphasized by Allah s.w.t in surah al-'Alaq verse 1-5:

Meaning:" Read with the name ofyour Lord who created (everything), He created man from a clot of blood. Read, and your Lord is the most gracious, who imparted knowledge by menas of the pen. He taught man what he did not know".

Ibn Kathir (1978: 780) also said, other than the Prophet Muhammad SAW, the previous prophets and apostles have also been guided after sincerely practicing tafakkur, khulwah and 'uzlah in order to seek the ultimate truth that can bring human out of darkness, ignorance and confusion according to holy scriptures that have been revealed such as al-Quran, Zabur, Taurat, Injil and Suhuf.

Next, Ibn Khaldun (1979: 70) concludes, elements in tasawwuf such as tafakkur, khulwah and dhikir is a noble practice that can purify other practices. The practice of tafakkur also is a way for practicing mujahadah and muhasabah which can increase faith and improve the quality of worship towards Allah SWT. 
However, al-Ghazzali (2005: 20) asserted, prior to dwelving and practicing tafakkur and other related elements, the salik must first understand the fundamentals of the Islamic law and teaching as to know what is cumpolsory to do, what is prohibited and what is permissible in Islam. Furthermore, can distinguish between clean thing and unclean thing then purificate from inner and outer impurities.

From the opinions and perspectives of the scholars on the above tafakkur practices, it can be concluded that tafakkur in tasawwuf is a method to know Allah SWT in earnest, to form a noble character, a pure heart and worship only for Allah SWT. It should be noted, other tasawwuf elements such as 'uzlah, khulwah, dhikir, riyadah and muraqabah needs attention too and should be practiced with the practice of tafakkur so the practice of tafakkur is perfect and achieving the objective.

\section{Practice of Tafakkur in Tasawwuf}

The development of tasawwuf practice and tarekat in Malaysia according to Harun (2015: 157) in his study titled Tasawwuf dan Tarekat: Sejarah Perkembangan dan Alirannya di Malaysia, the practice of tarekat in Malaysia begins with the arrival of preachers and traders from Arab in line with the date of inclusion of Islam in the Nusantara archipelago. There are many groups of tarekat who are active in Malaysia such as Naqshabandiyyah, Alawiyyah and Syadziliyyah tarekat.

Concerning tafakkur in tasawwuf also Rida (1990: 720-726) has quoted that tafakkur is one of the methods in tasawwuf that is obliged in the religion to purify themselves from sin in order to reach the the highest level of spirituality. As such, tafakkur becomes an important practice set out in the tasawwuf element.

For example, in relation to tafakkur in the Naqshabandiyyah order, Muhammad (1994: 12) explains in his study about Salik In Naqshabandiyyah, there are two forms to practice tafakkur. The general tafakkur is performed to reflect on the creatures created by Allah SWT. This type of tafakkur also does not require sitting position, a certain way and freely performed by anyone.

The specific tafakkur is contained in it kayfiyyat, specific body positions and should be guided by the teacher. For example, the salik should reflect and do the dhikir until he becomes calm and have the divine light in his heart. However, once the salik becomes senior then all the methods are no longer needed (Manam, 1994: 12).

To complete the tafakkur routine, Yusof (2004: 199) in his writings, 'The Naqshabandiyyah AlKhalidiyyah Order In Malaysia : A Critical Analysis Based On The Quran and Sunnah', the salik should always do the dhikir so that the salik's heart will always linked to Allah SWT and not deceived by the will of lust and the pleasure of the world. A salik also must earnestly performing worship.

While Mustafa (2013: 300) explains in his book Majmu ah al-Ahzab Syadziliyyah lilquțb Abi alhasan, according to Syadziliyyah, there are some important things to be considered by salik if they 
want to tafakkur. Among them, the salik must first seek repentance by doing the repentance prayer and seek forgiveness from Allah SWT from previous sins. After that, do the dhikir by mentioning the words tahlil, tahmid, tasbih, salawat and the holy verses of the Qur'an, as the readings help humans remember Allah SWT. As in His word in surah al-Jumuah verses 62:10:

Meaning: "Then once the Salah is over, disperse in the land, and seek the grace of Allah, and remember Allah abundantly, so that you may be successful".

Then, always remember to Allah SWT by doing the dhikir in secret so that, the reading of dhikir is completely absorbed in the heart and mind. After that, the tafakkur begins by emptying the mind except Allah SWT then thinking about the origin of His creation and the purpose of human created. Furthermore, salik should also reflect on the journey of salik's own heart (Diya al-Din, 2013: 300).

Omar (2012: 154) also stated that in the Naqshabandiyyah order, tafakkur and dhikir were the most important characteristic of the tasawwuf tarekat. Dhikir is intended to form the spiritual and the heart because the meaning of tafakkur itself means utterance and remembrance. Tafakkur acts as a memory amplifier to the heart and mind. In addition, the teacher is the most important element when it comes to make the right step for the salik and it is also as a reference and confirmation regarding the practice of tafakkur.

Sidek (1989: 22) insists, the reading of tafakkur in the Naqshabandiyyah order contains the holy verses from the al-Quran and salawat on the noblest of Prophet Muhammad SAW. Moreover, the salik should repeat three times the words 'llahi Anta maqșudi wa riḍaka mațlubi' to increase the conviction that Allah SWT sees and knows the state of their bodies and their souls.

Sidek (1989: 35) adds, though tafakkur is not specially restricted to a specific time and place. However, tafakkur and dhikir are usually done after the Maghrib prayer until the Isyak prayer and also after the Subuh prayer until the sun rises in the position facing the kiblat, choosing a comfortable place and a suitable place for worship. As the Prophet Muhammad SAW said in al-Syaykhani books of hadith, 2: 7743 which means:

"A man dhikir saying the name of Allh in isolation until his eyes run with tears".

Omar (2012: 120) also said that the Naqshabandiyyah order had two types of dhikir. First, dhikir Ismu al-Dhat. How to do this kind of dhikir is to mention the word Allah repeatedly in your heart and focus your mind on only Allah SWT. Second, dhikir Nafi Ithbat. The kalimah of this dhikir is La llaha Illa Allah, it is intended to remember Allah SWT and to remove the impurities that are in the heart.

While Valeria (2014: 4) also said that dhikir also aimed to avoid committing sin coming from tongue such as vain conversations, eliminating the passage of heart from syirik to Allah SWT despite the small things, instilling the love of Allah SWT and realizing the existence of Allah SWT that He truly exist thus denying another god besides Him. 
Then al-Falimbani (1932: 35) stated that one should compile and practice the dhikir or wirid in accordance based on the conditions of his life. For example, someone who has a family, working, studying and so on has certain and different obligation. Therefore, seek the right time to do the dhikir to always remember Allah SWT and avoid being negligent and at the same time can fulfill the obligations that have been accounted for.

Al-Baghdadi (1990: 217) also pointed out that reading the word dhikir is also the most important principle in tasawwuf and anyone who do the dhikir to Allah SWT will continue to receive the blessings of Allah SWT. Next, according to Shaykh al-Syadzili (2008: 51), fadhilat dhikir is able to open a secret of the heart and can control the desire of lust in the salik. Like the word of Allah SWT said in surah al-Ahzab, verses 33: 21 :

Meaning: "There is indeed a good model for you in the Messenger of Allah-for the one who has hope in Allah and the Last Day, and remembers Allah profusely".

In short, the practice of tafakkur in tasawwuf has several levels and forms. Among them are general and specific levels. The general level can often be done by anyone, like thinking about the natural phenomena. While the specific tafakkur should be done in orderly manner and received guidance from the teacher then accompanied by repentance. In addition, the reading of dhikir during the tafakkur helps salik control the mind, the heart and the feeling when practicing tafakkur in order to focus on Allah SWT as the main goal of tafakkur.

\section{Conclusion}

In conclusion, this study finds that tafakkur is a practice that demonstrates deep thinking to achieve the essence of knowledge and detached from blind taqlid in a matter. Therefore, the practice of tafakkur is also a practice that is based on the al-Quran, the hadith of the Prophet SAW, the agreement of the companions and the righteous to reflect on the signs and creations of Allah SWT. While for sufis or salik, they make tafakkur and other tasawwuf elements such as dhikir, khalwah, 'uzlah, riadah and muraqabah as the aim for acquiring al-Fana', al-Baqa' then to reach Ma 'rifah Allah.

\section{Acknowledgement}

This article sponsored and managed by the Center for Research and Innovation (RMIC), Sultan Zainal Abidin University (UniSZA), Gong Badak Campus 21300 Kuala Nerus, Terengganu, Malaysia

\section{References}

Muhammad, A. M. (1994). Salik Dalam Naqshabandiyyah. Kuala Lumpur: Universiti Malaya. Isa, A. Q. (2007). Haqaiq al-Tasawwuf. Syria: Dar al-'Irfan. Al-Kalabazi, A. B. (1998). Al-Ta`arruf li Madhabi Ahl al-Tasawwuf. Mesir: Dar al-Qaherah. Al-Baghdadi, A. Q. (1990). Al-Rasail al-Junayd. Qaherah: Bar`i Wajdai.

Al-Buți, S. R. (2010). Fiqh al-Sirah al-Nabawiyyah Ma`a Mujaz Li Tarikh Li al-Khilafah al-Rasyidah. Dimasyq: Dar al-Fikr. 
INTERNATIONAL JOURNAL OF ACADEMIC RESEARCH IN BUSINESS AND SOCIAL SCIENCES

Vol. 9, No. 4, April, 2019, E-ISSN: 2222-6990 @ 2019 HRMARS

Al-Ghazali, A. H. (1989). Minhaj al-Abidin Ila Jannati Rabba al-'Alamin. Bayrut: Mu'assasah al-Risalah Al-Ghazali, A. H. (2005). Ihya' Ulum al-Din. Al-Azhar: Dar al-Bayan.

Al-Ghazali, A .H. (2005). Mukasyafah al-Qulub, al-Muqarrab ila `Allam al-Ghuyub. Bayrut: Dar al-Kitab al-'Arabi.

Al-Munajjid, M. S. (2009). Al-Tafakkur. Saudi: Majmu`ah Zad.

Al-Qurțubi, M. (2005). Al-Jami' fi Aḥkam al-Qur'an. Bayrut: Maktabah al-`Așriyyah.

Al-Qusyairi, Z. D. (2003). Al-Risalah al-Qusyairiyyah fi 'llmi al-Tasawwuf. Bayrut: Dar al-Kitab al-'Arabi. Al-Sistani, A. (2008). Manhaj al-Șalihin al-'Ibadat al-Mu 'amalat. Lubnan: Dar al-Mu'arikh al-'Arabi.

Al-Suyuți, J. D. (2009). Tafsir al-Imamayni al-Jalalayni.Qaherah: Dar al-Hadith.

Al-Ṭusi, M. H. (2006). Ikhtiyar Ma 'rifah al-Rijal. Qaherah: Mu'assasah al-Nasyr al-Islami.

IbnKathir, I. U. (1978). Al-Bidayah Wa al-Nihayah . Dimasyq: Dar al-Fikr.

Hassan, A. B \& Khairuldin, W.M.K.F.W. (2019). Smart Quran Application: Authority of Digital Mushaf Usage in Malaysia. International Journal of Civil Engineering and Technology, 10(3). pp. 33153322.

Khairuldin, W. M. K. F. W., Anas, W. N. I. W. N., \& Embong, A. H. (2018). Experts' View within Fatwa Production in Malaysia. International Journal of Academic Research in Business and Social Sciences, 8(11), 530-538.

Khairuldin, W. M. K. F. W., Embong, A. H., Anas, W. N. I. W. N., Mohd, H. \& Ismail, D. (2018), The Application of Technology in the Dissemination of Fatwas: A Study on Religious Institutions in Malaysia, International Journal of Civil Engineering and Technology, 9(7). 1590-1596.

Khairuldin, W. M. K. F. W., Anas, W. N. I. W. N., Embong, A. H., Ismail, D. \& Hanapi, M.S. (2019). The Challenges of Fatwa Institutions in Malaysia in Facing the Progress of Science and Technology, International Journal of Mechanical Engineering and Technology, 10(4), 917-924.

Khairuldin, W. M. K. F. W., Embong, A. H., \& Anas, W. N. I. W. N. (2019). Technological Approach in Education of Musafir (Muslim Traveler) in Islam: The Study on Mobile App Mysafar. International Journal of Academic Research in Progressive Education and Development, 8(1), 40-47.

Khairuldin, W. M. K. F. W. (2018). Fatwa Role in Education and Legal Dispute in Malaysia. International Journal of Academic Research in Progressive Education and Development, 7(4), 295-302.

IbnQayyim, J. (2015). Miftah Dar al-Sa`adah. Lubnan: Dar ibn Ḥazm.

IbnTaymiyyah, A. (1989). Al-'Ubudiyyah. Qaherah: Dar al-Kalam Lil-Turath.

Sidek, J. (1989). Ajaran-Ajaran Tariqah Naqshabandiyyah Syaikh Muhammad Amin al-Kurdiy. Kuala Lumpur: Universiti Malaya

Auda, J. (2008). Maqasid al-Shariah ad Philosopyh of Islamic Law: A System Approach. Washington: The International Intitute of Islamic Thought.

Harun, M. F. (2015). Tasawwuf dan Tarekat: Sejarah Perkembangan dan Alirannya di Malaysia. Sintok: Universiti Utara Malaysia.

Yusof, M. R. (2004). Tarekat Naqshabandiyyah al-Khalidiyyah di Malaysia: Satu Analisis Kritis Berdasarkan al-Quran dan al-Sunnah.Selangor: Darulfikr.

Rida, M. R. (1990). Tafsir al-Manaral-Syaikh Muhammad 'Abduh. Mesir: al-Hay'ah al-Mișriyyah li alKitab. 
INTERNATIONAL JOURNAL OF ACADEMIC RESEARCH IN BUSINESS AND SOCIAL SCIENCES

Vol. 9, No. 4, April, 2019, E-ISSN: 2222-6990 @ 2019 HRMARS

Taqiuddin, M. (2009). Mahesi Sayedaw dan Al-Ghazali. Yogyakarta: Universitas Islam Negeri Sunan Kalijaga.

Omar, S. H. S. (2012). Zikir Allah, Allah, Allah...Jalan Menuju Hakikat dan Ma'rifatullah. Selangor: AlFalah Publications Snd Bhd.

Pramita, V. (2014). Resume Tasawwuf III Tentang Zikir. Indonesia: Agama Islam Negeri (IAIN). 